\title{
Safety Vision of Agricultural Tractors: An Engineering Perspective Based on Recent Studies (2009-2019)
}

\author{
Mario Fargnoli ${ }^{1,2, *(\mathbb{D})}$ and Mara Lombardi ${ }^{1}$ (D) \\ 1 Department of Chemical Engineering Materials Environment (DICMA), Sapienza-University of Rome, \\ via Eudossiana 18, 00184 Rome, Italy; mara.lombardi@uniroma1.it \\ 2 Ministry of Agriculture, Food and Fishery, DISR III, via XX Settembre 20, 00187 Rome, Italy \\ * Correspondence: mario.fargnoli@uniroma1.it
}

Received: 5 November 2019; Accepted: 17 December 2019; Published: 20 December 2019

\begin{abstract}
The high rate of injuries occurring in agricultural activities is of major concern in most countries, despite the ever-increasing efforts made at normative levels. In particular, the use of agricultural tractors is recognized as the most hazardous activity for farmers due to the large number of fatalities occurring every year. The aim of the present study was to investigate the recent developments in research activities dealing with tractor safety. For this purpose, a systematic literature review was carried out, taking into account engineering journal papers appearing in Scopus in the 2009-2019 period and focusing on tractor safety. As a result, 79 documents were selected and analyzed based on both their type (e.g., conceptual or empirical studies) and specific targets. They were then classified and discussed in accordance with a reference framework representing the main issues of agricultural tractor safety: mechanical hazards, protective devices, command and control, other hazards, ergonomics, information, conformity, and user behavior. The results of this analysis brought to light the need for a more human-centered approach when dealing with tractor safety. In addition, the lack of a reliable framework of technical standards was also stressed. Overall, despite the limitations due to the selection criteria, this study represents the first systematic literature review depicting the status of tractor safety in the engineering field, providing a basis for further research on the emerging themes outlined.
\end{abstract}

Keywords: tractor safety; agricultural machinery safety; agricultural activities; systematic literature review; research synthesis

\section{Introduction}

In recent years, awareness of occupational health and safety (OHS) issues has increased worldwide thanks to both the efforts made by national and international legislators, who have developed stricter and more thorough normative frameworks, and the spread of new approaches to safety problems in workplaces relying on "safety culture" and "safety management" concepts [1-4]. However, the number of occupational accidents and fatalities is not decreasing sufficiently. For example, as reported by Ivascu and Cioca [5], in European Union (EU) countries, the number of non-fatal incidents (i.e., those causing at least four calendar days of absence from work) was 3,127,546 in 2013, while in 2017 it reached $3,315,101$ cases. In these statistics, agricultural activities represent one of the most hazardous sectors. As confirmed by a recent report from the European Agency for Safety and Health at Work (EU-OSHA), fatalities in agriculture are three times higher than the average [6]. In non-European countries, this situation is very similar, including in the United States [7], Canada [8], Australia [9], and Korea [10].

The main causes of this phenomenon can be summarized as follows: the large number of small-sized and family-run companies; the great variety of outdoor activities carried out by the 
same operators and the consequent use of different tools and equipment; the seasonality of the work and the continuous change of workplaces; and the use of obsolete tractors and machinery, which are neither updated to comply with safety regulations nor in line with modern and safer technical solutions [11-14]. In fact, the number of aged tractors is very large, especially among family-run companies, for whom replacing them with newer and safer models [15] or even updating them [16,17] unaffordable from a financial point of view. For example, more than half of the tractors used in Italy (i.e., about 800,000 units) were put on the market before 1996. This means that numerous tractors used daily by farmers need to be updated to comply with recent safety requirements; in particular, the lack of a rollover protective structure (ROPS) is the most widespread and relevant non-conformity related to four-wheel tractors [18-20], despite the fact that overturning represents the leading cause of death among farmers [21,22]. This type of working equipment is very diffused and widely used in most agricultural activities, due to its multifunctional characteristics, ranging from use as a means of transportation in rural areas to its use for hauling a trailer or other working equipment (e.g., an atomizer, a plough, etc.), or as a static power unit (e.g., for running a pump or a saw bench through the tractor's power take-off (PTO)) [23-29]. Such multi-functionality has determined the tractor's classification as a vehicle and working equipment at the same time, meaning that from a safety point of view, an interwoven set of legislative requirements applies, contributing to the difficulties of both producers and users in guaranteeing an adequate safety level [18-20]. In such a context, it has been deemed that most injuries in agriculture are related to the use of tractors [14-16].

In the literature, numerous studies have investigated these safety issues, mainly focusing on specific topics such as tractors' technical features: e.g., ROPS [19,30], vibrations [31], ergonomics of commands [32], etc. Other studies have analyzed injuries related to this type of equipment in specific geographical contexts [33-37]. Further studies have addressed the problem considering the users' behavior and attitudes [38-40].

Given the great attention paid to these topics by researchers and practitioners of different disciplines, the goal of this study was to investigate the trends and challenges regarding tractor safety issues discussed in the literature from 2009 through to September 2019. Inspired by need to provide a thorough perspective of agricultural machinery safety, which has been demonstrated by several recent initiatives [41,42], this study aimed to provide a systematic analysis of engineering research on tractor safety. Hence, in line with the definition of systematic literature review provided by Moher et al. [43], the present study attempted to shed light on relevant evidence to answer the following research question: Which features and trends characterized the engineering research works on tractors' safety in the 2009-2019 period?

Accordingly, data collection was based on the analysis of articles published in engineering journals from 2009 to September 2019. Although such an approach could be considered limited due to the filtering criteria used, it certainly represents a first step towards the definition of a commonly shared research framework for agricultural tractor safety.

The remainder of the article is organized as follows: in the next section, the research methodology is illustrated, explaining the criteria used to perform the literature review. The results achieved are illustrated in Section 3 and a discussion is provided in Section 4. Section 5 concludes the paper and addresses further work.

\section{Materials and Methods}

The procedure used to carry out the systematic literature review (SLR) of scientific contributions dealing with tractor safety issues was based on the approach proposed by Thomé et al. [44], which can be summarized in the following main steps:

1. Identification of material (definition of the scope, the database, and search criteria);

2. Screening of pertinent articles (application of search criteria);

3. Eligibility evaluation (abstract analysis for inclusion/exclusion);

4. Data analysis and synthesis (full-text review). 
This procedure is consistent with the Preferred Reporting Items for Systematic Reviews and Meta-Analyses (PRISMA) guidelines [43], which are a widely recognized tool for review studies in the safety field [45]. Following the research goal defined in the previous section, the studies registered in the Scopus database from 2009 to 2019 (up to September 2019) were considered, first selecting those papers with keywords including the following search strings: "tractor" and "safety" (Research A); "machine*" and "safety" and "agricultur" (Research B); "machine*" and "safety" and "farm*" (Research C). The results of this first step consisted of 275 documents for Research A, 230 for Research B, and 53 for Research C (558 documents in total). Next, journal articles (i.e., excluding conference papers and book chapters) published in English were selected and among those, those classified in the "Engineering" field were filtered, returning 109 (Research A), 53 (Research B), and 15 (Research C) documents (177 in total). The details of this search are provided in the Supplementary Materials. The main reasons for the above criteria, according to which the first screening was carried out, are as follows. The Scopus database is one of the most diffused and well-known databases of peer-reviewed academic and scientific documents, of which the performance, especially in the natural science and engineering fields, are considered comparable or superior to other databases of peer-reviewed articles [46]. The choice to limit the analysis to the engineering field aimed to provide a specific point of view of a problem that at a general level entangles different subject areas (and journals), such as agronomy, medicine, engineering, etc. The definition of a specific subject area is a key factor for performing a reliable systematic literature review [47].

Further filtering was carried out by reading the abstracts of all these documents and selecting those addressing agricultural (four-wheeled and tracked) tractor safety issues. Thus, studies focusing on lawn tractors, off-road utility vehicles, gardening machinery, two-wheeled tractors, and similar types of machinery/vehicles were excluded, as well as those articles discussing OHS issues among farmers in general. Conversely, papers discussing safety training of the users of agricultural tractors were taken into account in the analysis, as this training is mandatory in most countries and, in some cases (e.g., in Italy), a specific competency qualification of professional users is required. The output of this analysis led to a final list of 79 documents; an overview of the selection process is shown in Figure 1.

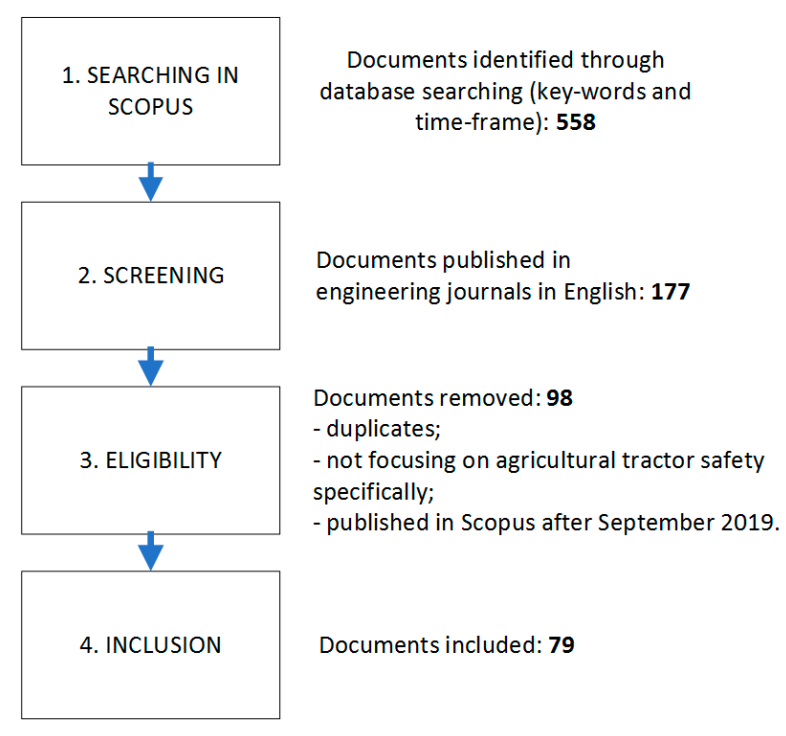

Figure 1. Selection process of the documents analyzed.

Data analysis and synthesis were then carried out by going through the documents' full text. In doing this, the approaches proposed by Carnevalli and Cauchick Miguel [48] and Verbano and Venturini [49] were used, tailored to the specific context of this study. Accordingly, the papers obtained from the selection process were classified from different points of view: 
1. Type of publication: i.e., the engineering journals that published the selected documents, the affiliation country of the first author when the paper was published, the year of publication, etc.

2. Research category: distinguishing the selected documents into empirical and conceptual works. In detail, adapting the criteria provided by the above-mentioned studies $[48,49]$ to the context of agricultural tractor safety, we considered:

- "empirical study": a research work focused on the development of novel technical solutions, the practical test of the performances of the tractor and its components, as well as articles undertaking surveys and case studies;

- "conceptual study": a research work aimed at providing theoretical concepts, review works, simulations, or theoretical modeling.

Based on this, a more detailed classification was performed, dividing empirical studies into the following subcategories:

- E-S: empirical study based on surveys and interviews;

- E-T: empirical study based on practical testing of real equipment and user behavior;

- E-N: empirical study providing a novel technical solution, e.g., a prototype.

As far as conceptual works are concerned, the following subcategories were defined:

- C-D: studies based on data collection and analysis (e.g., accident statistics);

- C-M: studies providing software simulation and modeling;

- C-R: works focusing on a literature review.

These sub-categories refer to the target of each study and the means used to achieve it. For instance, if an article proposed an assessment model for which validation is carried out through a practical case study, the paper was classified as C-M (and not as E-T), since it aimed to provide a conceptual output.

3. Research streams: i.e., the classification of documents in accordance with a reference framework representing the main issues of agricultural tractor safety. This analysis was aimed at investigating the research trends related to tractor safety in the engineering field, underlining the aspects dealt with by the selected documents [50,51]. For this purpose, as a classification benchmark, the following research streams were used:

S.1. Mechanical hazards (stability, mobility, entanglement, etc.);

S.2. Protective devices (ROPS, FOPS, PTO shield, etc.);

S.3. Command and control (steering system, etc.);

S.4. Other hazards (e.g., vibrations, noise, etc.);

S.5. Ergonomics (technical features related to: user comfort, actuation forces, visibility, etc.);

S.6. Information (safety signs, operational and warning signals, user training, etc.);

S.7. Conformity (i.e., compliance with technical standards and mandatory requirements both from the constructive and users' standpoints);

S.8. User behavior (safety attitudes and behavior of users, human error, etc.).

These research streams were selected following the approach proposed by the Machinery Directive [52], which in its Annex I provides a clear framework of safety requirements related to machinery and its mobility. This choice was also motivated by the nature of the selected papers, which dealt with machinery safety in an engineering context. Hence, while one might reasonably argue that subjects such as safety signs or vibrations should be included in the ergonomics area, the use of the Machinery Directive approach as reference framework allowed us to use a widely recognized scheme 
from an engineering point of view. This included the research stream S.8. (user behavior) reflecting the need to take into account the "reasonably foreseeable misuse" or readily predictable human behavior of machinery users. This aspect is strictly related to the design and risk assessment of machinery, which require a human-centered approach [53] to consider human behaviors performed in work activities related to the use of equipment, taking into account foreseeable errors during its operation [54-56]. Similarly, training activities of tractor users are considered a relevant topic in machinery safety [57] and were included in the stream S.6. Moreover, this classification was in line with safety issues related to agricultural tractors provided by the International Labour Office (ILO) Code of practice concerning safety and health in agriculture [58], which is recognized by many studies as a worldwide reference document for OHS in agricultural activities [59,60].

To make this analysis more reliable and replicable, it was carried out independently by both the authors, in line with the research cues suggested by Vinayak and Kodali [61].

\section{Results}

\subsection{Type of Publication}

The selected documents were published by 25 different engineering journals covering a wide range of engineering topics (Table 1).

Table 1. List of journals in alphabetical order.

\begin{tabular}{c} 
Journal Names \\
Accident Analysis and Prevention \\
Applied Engineering in Agriculture \\
Applied Ergonomics \\
Biosystems Engineering \\
Contemporary Engineering Sciences \\
Engineering in Agriculture, Environment and Food \\
Ergonomics in Design \\
IEEE Sensors Journal \\
IFAC-PapersOnLine \\
International Journal of Agricultural and Biological Engineering \\
International Journal of Commercial Vehicles \\
International Journal of Occupational Safety and Ergonomics \\
International Journal of Reliability and Safety \\
International Journal of Safety and Security Engineering \\
Journal of Agricultural Engineering \\
Journal of Agricultural Safety and Health \\
Journal of Safety Research \\
Journal of Terramechanics \\
Journal of the Institution of Engineers (India) \\
Mechanics and Industry \\
Transactions of the ASABE \\
Saternational Journal of Commercial Vehicles \\
Safety \\
Safety Science \\
Sensors \\
\hline
\end{tabular}

The distribution of publication year in the selected period is reported in Figure 2, where the highest numbers of publications belonged to 2018 and 2016. In 2018, the number of journals where the documents were published was greater, while in 2016 the larger number of publications belonged to a specific special issue [62].

Concerning the affiliation of the first author, as shown in Table 2, the majority of papers were published by researchers from the USA and European countries (mainly Italy and Spain). 


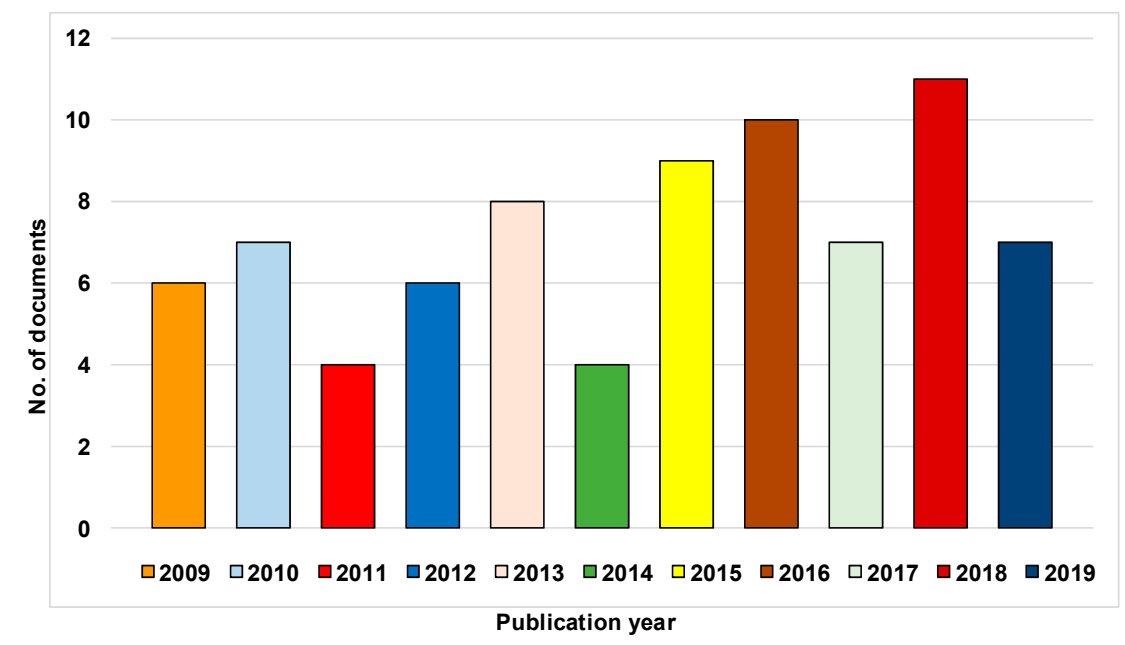

Figure 2. Number of published articles per year.

Table 2. Number of articles per country.

\begin{tabular}{cc}
\hline Country & No. \\
\hline USA & 32 \\
Italy & 27 \\
Spain & 5 \\
Japan & 3 \\
India, Iran & 2 \\
Australia, Canada, China, France, Israel, Kuwait, Korea, Turkey & 1 \\
\hline
\end{tabular}

\subsection{Research Categories}

The next step of the analysis consisted of identifying the specific objective of each document-by going through the text, the goal of the studies was identified. This also allowed us to categorize them following the criteria explained in the previous section. Figure 3 reports the number of empirical and conceptual studies is reported in percentages.

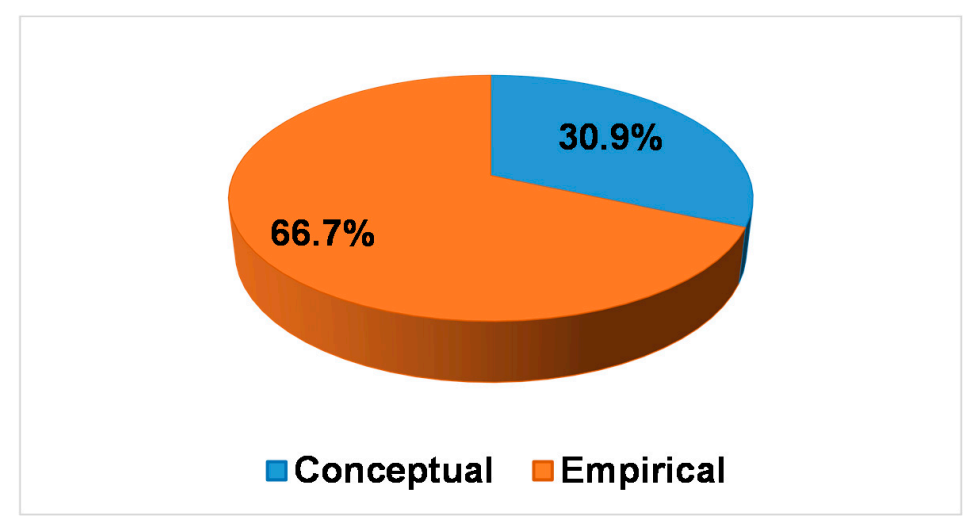

Figure 3. Number of empirical and conceptual studies in percentages.

Within the subcategories, most empirical studies discussed the results of surveys among tractor users and experts, while the majority of conceptual works were focused on simulations and modeling (Figure 4). Among the latter only one review paper was found, concerning the training programs for the safe use of tractors and agricultural machinery among youth [63]. This supports the research motivations of the present study, highlighting the lack of thorough literature reviews on tractor safety. 


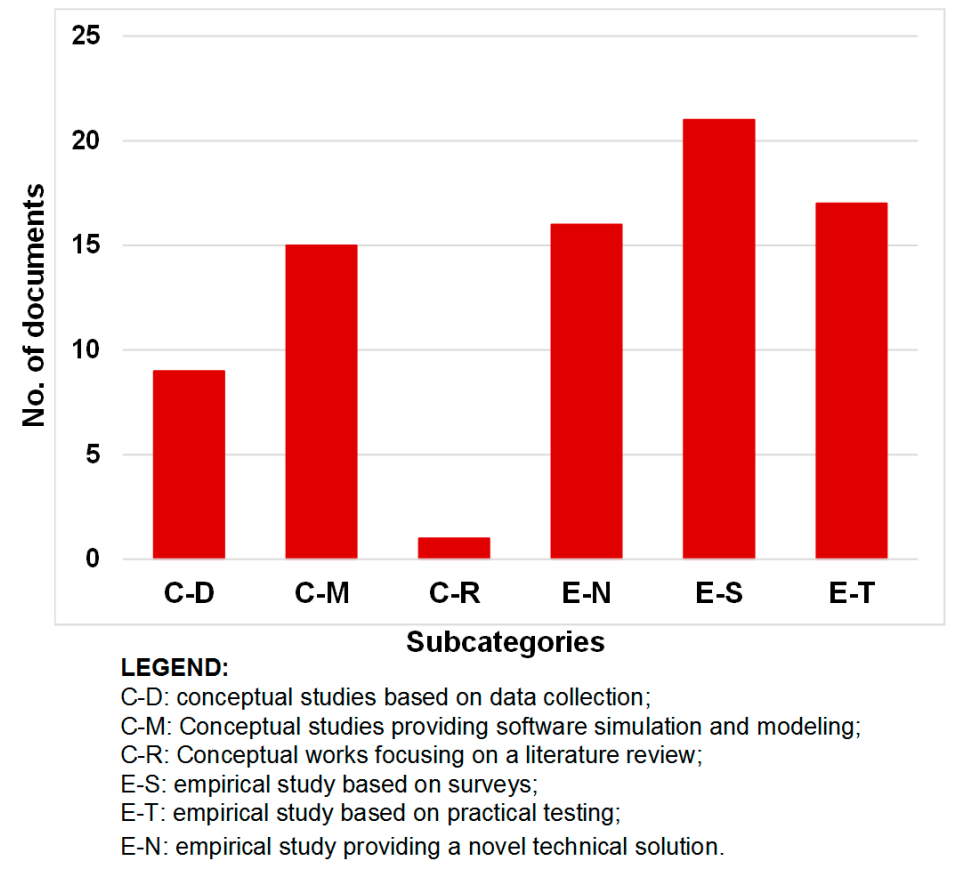

Figure 4. Number of articles in each subcategory.

\subsection{Research Streams}

Finally, the research issues addressed by the selected articles were investigated. The analysis consisted of defining the research target of each document, i.e., which topics were investigated by the studies in order to enhance tractor safety. The results of this analysis are summarized in Figure 5, which shows that most studies dealt with conformity and user behavior issues, whereas documents addressing hazards due to mechanical and other sources were less numerous. The full list of the documents with the assigned reference number, subcategory codes and the related research stream is reported in Appendix A, while the following subsections provide a more detailed description of them.

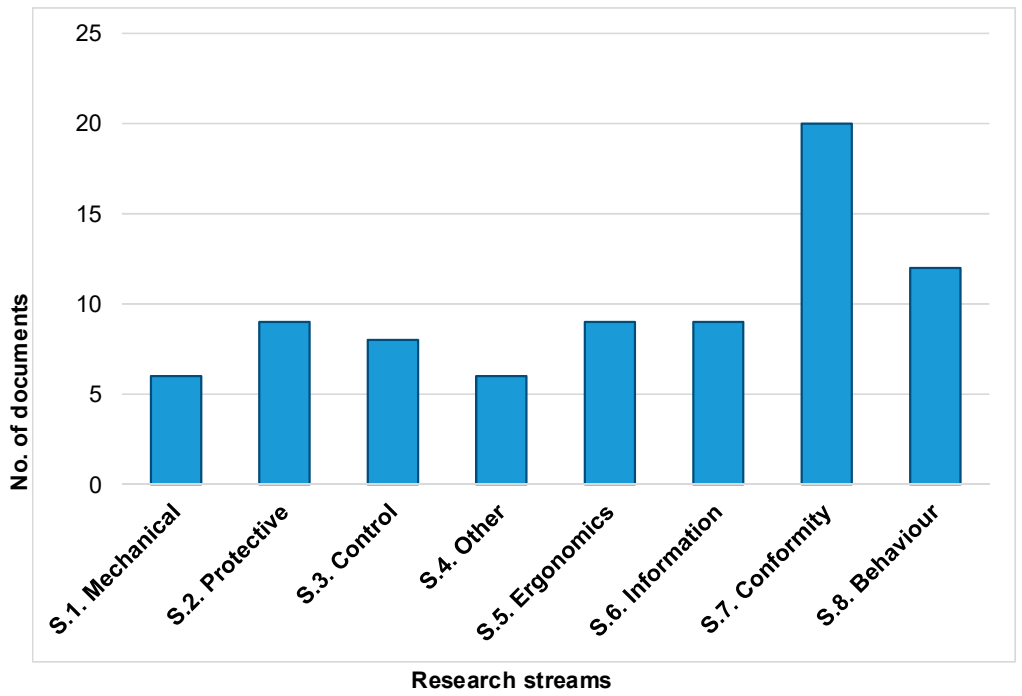

Figure 5. Number of articles in each research stream.

\subsubsection{Mechanical Hazards}

Regarding the mechanical hazards, most studies addressed the stability problems of tractors. The effects of the presence of different types of ROPS on the stability of narrow-track tractors was 
investigated by Franceschetti et al. [64], while Mazzetto et al. [65] studied a kinematic model for analyzing the lateral stability of an articulated narrow-track model moving uphill. The effects of the repositioning of liquids on the center of gravity was investigated by Khorsandi et al. [66]. A prototype of a triangular rubber track unit to replace tires was proposed by Franceschetti et al. [67] to reduce the probability of loss of stability, whereas other studies investigated the reliability problems related to the three-point hitching system to use the maximum hydraulic lifting capacity safely [68], as well as the improvement of the linkage and control valves [69].

\subsubsection{Protective Systems}

The research on protective systems of tractors is largely characterized by studies on ROPS. These studies aimed to augment the structural protection effectiveness by analyzing the maximum mass, which is used as reference mass in the Code 4 and SAE J2194 Standard tests [70]; the behavior of size-extended models [71]; and the energy dissipation capability augmented by the insertion of an energy absorption disc [72]. Other studies investigated the performances of novel types of ROPS aimed at preventing the unsafe behavior of users, such as the AutoROPS [73] and the compact rollover protective structure (CROPS) [74,75]. Interestingly, it should be noted that in the latter papers, the acronym "CROPS" referred to a modified ROPS for narrow-track tractors developed by Italian researchers from the Italian Workers Compensation Authority (INAIL). The same acronym was used differently in other works to indicate the "cost-effective roll-over protective structure" program by the National Institute for Occupational Safety and Health (NIOSH), which aimed to promote the retrofitting of ROPS among USA farmers with tractors without ROPS, as reported by Ayers et al. [76]. In this study, a computer-based ROPS design program was developed and tested via the design of three different types of structures. Additionally, studies dealing with the safety characteristics of the actuation force of different foldable two-post ROPS [77] and the design of a falling-object protective structure (FOPS) integrating an existing two-post rear ROPS [78] were included in the stream S.2.

\subsubsection{Command and Control}

Research on the improvement of command and control systems was essentially focused on studies related to the implementation of automated solutions for the steering [79] and hitching [80] systems. Similarly, Ruggeri et al. [81] developed a smart dashboard and machine controller to monitor the functional safety performance level of tractors. Moreover, the development of devices for monitoring the engine and other utilities of the tractor, as well as the reliability of the ball-joint-placed steering actuator and the wheel spindle [82] were proposed. Additionally, Rovira-Mas [83] developed a sensor architecture for monitoring the main tractor performance. In this research area, we also included the studies on the development of navigation systems to be used in autonomous robot tractors [84,85], as well as the study of a warning system to be used during the rearward use of the tractor [86].

\subsubsection{Other Hazards}

Regarding other types of hazard, five studies dealt with problems related to the transmission of whole-body vibrations to the operator. Catania et al. measured the exposure for the operator driving both a wheeled and a tracked tractor while performing different working activities [87]; other studies focused on the definition of an exposure index in relation to the different types of tractor [88] or to different terrain surfaces [89-91]. In addition, Sviridova and Sakai [92] investigated the effects of noise on the operator's cardiovascular system considering different engine speeds.

\subsubsection{Ergonomics}

Ergonomics issues were investigated by focusing different aspects. Rakhra and Mann analyzed the operator's reaction time and response errors during monitoring of rear-mounted equipment [93]. Ehlers and Field investigated the visibility features of tractors to enhance rearward visibility [94,95], while Gilad and Byran [96] focused their attention on modeling the tractor operators' field of view. 
Other studies dealt with the analysis of the actuation forces needed to operate foldable rollover protective structures (FROPSs) [97,98], whereas Pessina et al. [99] compared the handling load of different narrow-track tractors' FROPSs with the related grasping area. Furthermore, two studies describing field tests aimed at setting a warning device based on the operative conditions of the tractor $[100,101]$ were included in this research stream.

\subsubsection{Information}

Several studies investigated the information provided to the tractor users by means of safety signs and pictograms put on the machinery [102-104], as well as in user manuals [105]. Other studies focused their attention on training courses for tractor operators [63,106,107]. Bertacchini et al. [108] paid attention to the development of driver assistance devices and warning systems to alert users in case of hazardous situations such as the loss of stability. In this group of papers, we also included the paper by Liu and Koc [109] describing the development of a detection and emergency notification system.

\subsubsection{Conformity}

Among the selected documents, the majority focused on the conformity aspects of tractor safety and three main research substreams were found. First, the analysis of the status of compliance with safety regulations among farmers (mainly related to the installation of ROPS and seat-belts) was widely carried out [20,110-112], also considering the incidence of the occurrence of rollover [113]. The second aspect concerned the conformity to technical standards, which mainly focused on ROPS testing codes such as SAE J2194 [114-116], OECD Code 3 [117], OECD Code 4, and OECD Code 6 [118], or their combined use [119-121]. Similarly, the conformity to technical standards concerning whole-body vibrations was analyzed by Kabir et al. [122]. Thirdly, the risk assessment of activities related to the use of tractors based on specific work tasks [123] and the development of risk scenarios based on the analysis of rollover fatalities were investigated [21]. Furthermore, in this research area we included studies which analyzed the problem of safety compliance of tractors at both the strategic $[34,124]$ and market level [125], as well as the development of proper equipment for tractor testing [126].

\subsubsection{User Behavior}

The number of research works dealing with the behavior of the operators is also noteworthy. In particular, most studies included in this research stream investigated the user attitude towards safety practices and risk-taking behavior [18,127-129], including their perception of safety issues [37]. Jenkins et al. [130] surveyed motivations and barriers to the safe use of tractors among farmers. Accordingly, surveys were carried out also during specific demonstrations related to ROPS retrofitting [131,132]. Di Nocera et al. [133] analyzed the tractor's operator attentional control, while Lleras et al. [134] investigated the behavior of tractor operators in rollover-prone situations. Furthermore, tasks and activities carried out by the operators when using the tractor [135] and when they were involved in overturn-related fatal and nonfatal injuries [136] were investigated.

\section{Discussion}

\subsection{Discussion of Research Trends}

Merging the results obtained from the analysis and synthesis of the selected documents some implications can be outlined.

First, the attention paid to the behavior of users was largely investigated not only by specific studies (research stream S.8), but also across different areas, such as the development of ROPS solutions. For example, some studies investigated the behavior of compact ROPS [74,75] and auto-ROPS [73], which are both technical solutions aimed at bypassing the (foreseeable) dangerous behavior of the operator when using a tractor equipped with a foldable structure (research stream S.2). In line with this aspect, other studies addressed the proper comprehension of safety signs and pictorials [102-105], 
highlighting the importance given to human factors (research stream S.6). In addition, documents reporting efforts made to augment the safety culture/attitudes of farmers, promoting the use of ROPS and seatbelts, were consistent with such an address $[37,127,128,130,136]$. These research trends confirm that "safety is, above all, behavioral and individual" [53], promoting a human-centered approach in the field of tractor safety. Accordingly, the works of Di Nocera et al. [133] and Rakhra and Mann [93], addressing cognitive failures of the tractor operator and its reaction time and response errors, can be considered consistent with this emerging theme in recent woks on tractor safety.

Another emerging aspect from this review was related to the geographical differences among the selected documents. While most of the documents analyzed in this study focused on ROPS retrofitting, the majority of studies carried out in the USA and Australia described activities related to national programs aimed at increasing the number of ROPS retrofitted tractors through surveys among farmers and other stakeholders. Conversely, the majority of studies by European researchers that focused on ROPS (especially in Italy and Spain) were aimed at augmenting knowledge on the technical performances of aftermarket structures by means of field and laboratory tests. These works investigated ROPS testing procedures with the goal of verifying their reliability in practical contexts, especially those related to the assessment of aftermarket structures. On the one hand, studies dealing with ROPS retrofitting could be expected, since the highest number of fatalities and serious injuries with tractors are due to loss of stability (i.e., overturns) and the number of old tractors without ROPS is still large worldwide.

Two different research trends emerged, the former fostering the farmers' safety attitude, the latter focusing on the features and conformity to technical standards of ROPSs (e.g., the respect of the clearance zone), particularly for aftermarket solutions. Consequently, the following implications can be derived:

1. The lack of studies promoting ROPS retrofitting and user training programs in other countries (e.g., in the European Union) could reveal the need to implement/increase these activities in such places. In fact, although the Directive 2009/104/EC indicates that self-propelled work equipment should be driven only by workers who have been appropriately trained in the safe use of such equipment [137], training and competence qualifications of tractor users have not been discussed sufficiently.

2. There is a need to improve the effectiveness and usability of technical standards for ROPS testing and homologation, so as to make ROPS design and manufacturing easier and less expensive [73,76], while avoiding at the same time the failure of homologated protective structures [70]. The latter issue was stressed by different studies, shedding light on the necessity of updating technical standards such as the OECD Codes, taking into account the features of modern tractors (e.g., the tractor ballast [120]) and how they are used in practice [65,118]. Similarly, the lack of a clear reference for dynamic tests of ROPS was outlined $[117,126]$, while the inadequacy of the standards related to FROPSs testing (e.g., concerning the grasping area [99] and the actuation torque [97]) needs to be further investigated.

Furthermore, several studies investigated novel solutions in line with the " 4.0 era" [138]. In fact, some works proposed devices for monitoring the tractor components' status to augment its safe use $[79,81,82,108]$. Others investigated solutions to augment the visibility of the operator $[64,94,95]$, while two Japanese works proposed advanced solutions for navigation systems for unmanned tractors $[84,85]$.

It is noteworthy to mention the studies addressing warning and alert systems to augment the operator's risk perception [86,101], and detection and emergency notification systems in case of overturn [109]. They outlined the need to foster the integration of a warning device to alert the operator in case of hazardous situations. In particular, monitoring the tractor's stability during operation could greatly contribute to preventing fatal accidents when using narrow-track tractors equipped with FROPS. The proposal of an AutoROPS [73] could also be promising, even though the solution 
designed for the deployment of the structure in the event of tractor rollover was not addressed in the paper specifically.

Accordingly, the results of the present study showed that although not many studies dealt with this emerging research field, the potential to augment tractor safety by means of automated solutions relying on Industry 4.0 means are great, and deserving of further consideration.

\subsection{Limitations}

The results obtained from this review were certainly affected by the limitations that characterize any review study, i.e., the criteria used for searching and screening the documents, such as the target analysis, keywords, and type of publication. In particular, the choice of limiting the analysis to engineering journals only excluded numerous relevant works published in journals classified in Scopus into different subject areas, such as medicine and agricultural and biological sciences. Although the selection of documents within a specific subject area is recommended when performing a reliable systematic literature review [47,139], this certainly diminished the general validity of the study. Consequently, the output of the study cannot be considered exhaustive and it must be evaluated in that specific context [45]. However, the proposed criteria for the data analysis and synthesis can be considered a basis for further research works addressing both the agricultural context and safety issues in different sectors.

\section{Conclusions}

This study aimed to provide an overview of tractor safety in the engineering field. With this goal in mind, 79 engineering journal articles published in Scopus in the 2009-2019 period were analyzed by means of a systematic literature review approach. The identified sample of documents was deemed to sufficiently represent the recent targets and trends on tractor safety research. Moreover, the fact that these studies were very diverse in terms of sectorial (i.e., journal source), technical (i.e., the scientific approach used), and geographical background provided a realistic overview of the cutting edge in this specific context. A set of research streams based on the main issues of agricultural tractor safety was used to analyze the contents of the selected documents.

The review shed light on the emerging themes that academics and researchers are dealing with in order to reduce the number of injuries related to the use of agricultural tractors. The proposed framework for classifying the selected studies allowed us to better highlight the different engineering perspectives of tractor safety. In particular, the attention paid to retrofitting ROPS on older tractors came forth as the most relevant safety issue worldwide. The analysis revealed that different approaches have been applied, ranging from users' involvement in surveys aimed at increasing their safety attitudes and consciousness, to the implementation of computational models and field tests for the verification of testing procedures.

The study also brought to light the different user-centered approaches aimed at reducing the unsafe behavior of operators. This could provide useful insights to researchers and practitioners on potential improvements from different points of view, especially taking into account the possibilities offered by the newest technologies.

Overall, the merit of this study can be considered twofold. On the one hand, it represents a first attempt to describe up the status of tractor safety in the engineering field by means of a systematic literature review, providing a framework for the analysis and synthesis of documents in this specific context, which could allow us to bring to light research streams and emerging themes proposed in recent literature. On the other hand, since review studies can augment knowledge on specific issues, providing evidence on trends and challenges in a systematic manner [43,44], the output of this work could be used for future studies to extend the knowledge on safety issues not only in agricultural activities, but also in other contexts where the use of machinery and work equipment represents the main cause of severe injuries. 
Supplementary Materials: The following are available online at http://www.mdpi.com/2313-576X/6/1/1/s1.

Author Contributions: Conceptualization, M.F., M.L.; methodology, M.F., M.L.; validation, M.F., M.L.; writing, review and editing, M.F., M.L. All authors have read and agreed to the published version of the manuscript.

Funding: This research received no external funding.

Conflicts of Interest: The authors declare no conflict of interest.

\section{Appendix A}

List of the selected documents organized per research streams, where research categories were organized as follows:

E-S: empirical study based on surveys and interviews;

E-T: empirical study based on practical testing of real equipment;

E-N: empirical study providing a novel technical solution, e.g., a prototype;

C-D: conceptual studies based on data collection and analysis (e.g., accident statistics);

C-M: conceptual studies providing software simulation and modeling;

C-R: conceptual works focusing on a literature review;

and research streams were individuated by the following codes:

S.1: Mechanical hazards;

S.2: Protective devices;

S.3: Command and control;

S.4: Other hazards;

S.5: Ergonomics;

S.6: Information;

S.7: Conformity;

S.8: User behavior.

\begin{tabular}{ccccc}
\hline No. & Author & Year & Category & Stream \\
\hline$[8]$ & Ahamed et al. & 2009 & E-N & S.3 \\
{$[78]$} & Al-Bassit et al. & 2019 & E-N & S.2 \\
{$[70]$} & Alfaro et al. & 2010 & C-M & S.2. \\
{$[73]$} & Alkhaledi et al. & 2013 & E-N & S.2. \\
{$[119]$} & Arana et al. & 2011 & C-M & S.7. \\
{$[76]$} & Ayers et al. & 2016 & C-M & S.2. \\
{$[108]$} & Bertacchini et al. & 2014 & E-N & S.6. \\
{$[69]$} & Bhondave et al. & 2017 & E-N & S.1 \\
{$[126]$} & Bietresato et al. & 2018 & E-N & S.7 \\
{$[79]$} & Bo et al. & 2018 & E-N & S.3 \\
{$[102]$} & Caffaro and Cavallo & 2015 & E-S & S.6 \\
{$[103]$} & Caffaro et al. & 2017 & E-S & S.6 \\
{$[104]$} & Caffaro et al. & 2018 & E-S & S.6 \\
{$[100]$} & Casazza et al. & 2016 & E-T & S.5 \\
{$[82]$} & Castagnetti et al. & 2015 & E-N & S.3 \\
{$[87]$} & Catania et al. & 2013 & E-T & S.4 \\
{$[136]$} & Cole et al. & 2016 & E-S & S.8 \\
{$[110]$} & Cole et al. & 2009 & C-D & S.7 \\
{$[89]$} & Cutini et al. & 2012 & E-S & S.4 \\
{$[90]$} & Cutini et al. & 2016 & E-T & S.4 \\
{$[91]$} & Cutini et al. & 2017 & E-T & S.4 \\
{$[88]$} & Cutini et al. & 2019 & E-T & S.4 \\
{$[133]$} & Di Nocera et al. & 2018 & E-S & S.8 \\
\hline
\end{tabular}




\begin{tabular}{|c|c|c|c|c|}
\hline No. & Author & Year & Category & Stream \\
\hline [94] & Ehlers and Field & 2017 & E-T & S.5 \\
\hline [95] & Ehlers and Field & 2016 & E-T & S.5 \\
\hline [86] & Ehlers et al. & 2017 & E-T & S.3 \\
\hline [123] & Fargnoli et al. & 2018 & E-S & S.7 \\
\hline [67] & Franceschetti et al. & 2016 & $\mathrm{E}-\mathrm{N}$ & S.1 \\
\hline$[77]$ & Franceschetti and Rondelli & 2019 & E-T & S.2 \\
\hline$[64]$ & Franceschetti et al. & 2019 & E-T & S.1 \\
\hline [96] & Gilad and Byran & 2015 & C-M & S.5 \\
\hline$[71]$ & Guan et al. & 2011 & E-N & S.2 \\
\hline [118] & Guzzomi and Rondelli & 2013 & C-D & S.7 \\
\hline [131] & Hard et al. & 2015 & E-S & S.8 \\
\hline [132] & Hard et al. & 2016 & E-S & S.8 \\
\hline [111] & Hard and Myers & 2011 & C-D & S.7 \\
\hline [114] & Harris et al. & 2010 & E-T & S.7 \\
\hline [115] & Harris et al. & 2011 & C-M & S.7 \\
\hline [37] & Houshyar and Houshyar & 2018 & E-S & S.8 \\
\hline [120] & Jarén et al. & 2009 & C-M & S.7 \\
\hline [130] & Jenkins et al. & 2012 & E-S & S.8 \\
\hline [106] & Jepsen & 2012 & E-S & S.8 \\
\hline [34] & Jones et al. & 2013 & C-D & S.7 \\
\hline [122] & Kabir et al. & 2017 & E-T & S.7 \\
\hline$[84]$ & Kaizu and Choi & 2012 & $\mathrm{E}-\mathrm{N}$ & S.3 \\
\hline [127] & Keskin et al. & 2012 & E-S & S.8 \\
\hline [97] & Khorsandi and Ayers & 2018 & E-T & S.5 \\
\hline$[66]$ & Khorsandi et al. & 2018 & C-M & S.1 \\
\hline [98] & Khorsandi & 2016 & C-M & S.5 \\
\hline$[72]$ & Latorre-Biel et al. & 2019 & E-N & S.2 \\
\hline [117] & Lindhorst et al. & 2018 & C-M & S.7 \\
\hline [109] & Liu and Koc & 2015 & E-N & S.6 \\
\hline [134] & Lleras et al. & 2016 & E-N & S.8 \\
\hline [135] & Lombardi and Fargnoli & 2018 & C-M & S.8 \\
\hline [63] & Mann and Dee Jepsen & 2017 & C-R & S.6 \\
\hline$[65]$ & Mazzetto et al. & 2013 & C-M & S.1 \\
\hline [74] & Monarca et al. & 2013 & E-T & S.2 \\
\hline$[75]$ & Monarca et al. & 2015 & C-D & S.2 \\
\hline$[20]$ & Myers et al. & 2009 & E-S & S.7 \\
\hline [125] & Myers and Purschwitz & 2012 & C-D & S.7 \\
\hline [99] & Pessina et al. & 2016 & E-T & S.5 \\
\hline [116] & Poojary and Kalamkar & 2009 & C-M & S.7 \\
\hline [93] & Rakhra and Mann & 2013 & E-T & S.5 \\
\hline$[21]$ & Rondelli et al. & 2018 & C-D & S.7 \\
\hline [121] & Rondelli and Guzzomi & 2010 & C-D & S.7 \\
\hline [101] & Rondelli et al. & 2013 & C-M & S.5 \\
\hline [83] & Rovira-Más & 2010 & C-M & S.3 \\
\hline [81] & Ruggeri et al. & 2014 & E-N & S.3 \\
\hline [18] & Schwab et al. & 2019 & E-S & S.8 \\
\hline$[68]$ & Seyedabadi & 2015 & C-M & S.1 \\
\hline [113] & Sorensen et al. & 2010 & E-S & S.7 \\
\hline [92] & Sviridova and Sakai & 2015 & E-T & S.4 \\
\hline [85] & Takai et al. & 2014 & E-N & S. 3 \\
\hline [105] & Tebeaux & 2010 & E-S & S.6 \\
\hline [128] & Tillapaugh et al. & 2010 & E-S & S.8 \\
\hline [124] & Tinc et al. & 2015 & C-D & S.7 \\
\hline [112] & Tonelli et al. & 2009 & E-S & S.7 \\
\hline [107] & Vincent et al. & 2019 & E-S & S.8 \\
\hline [129] & Weil et al. & 2014 & E-S & S.8 \\
\hline
\end{tabular}




\section{References}

1. Cecchini, M.; Cossio, F.; Marucci, A.; Monarca, D.; Colantoni, A.; Petrelli, M.; Allegrini, E. Survey on the status of enforcement of European directives on health and safety at work in some Italian farms. J. Food Agric. Environ. 2013, 11, 595-600. [CrossRef]

2. Vigoroso, L.; Caffaro, F.; Cavallo, E. Warning against Critical Slopes in Agriculture: Comprehension of Targeted Safety Signs in a Group of Machinery Operators in Italy. Int. J. Environ. Res. Public Health 2019, 16, 611. [CrossRef] [PubMed]

3. Fargnoli, M.; Lombardi, M.; Haber, N.; Puri, D. The Impact of Human Error in the Use of Agricultural Tractors: A Case Study Research in Vineyard Cultivation in Italy. Agriculture 2018, 8, 82. [CrossRef]

4. Kim, H.; Lee, K.; Räsänen, K. Agricultural injuries in Korea and errors in systems of safety. Ann. Agric. Environ. Med. 2016, 23, 432-436. [CrossRef]

5. Ivascu, L.; Cioca, L.-I. Occupational Accidents Assessment by Field of Activity and Investigation Model for Prevention and Control. Safety 2019, 5, 12. [CrossRef]

6. European Agency for Safety and Health at Work (EU-OSHA). Maintenance in Agriculture-A Safety and Health Guide; Publications Office of the European Union: Luxembourg, 2011. [CrossRef]

7. Burgus, S.; Duysen, E. Identifying Topics and Dissemination Methods for Agricultural Safety and Health Messages. Safety 2017, 3, 3. [CrossRef]

8. Canadian Agricultural Injury Reporting (CAIR). 2016. Available online: https://www.cair-sbac.ca/wpcontent/uploads/2017/02/CASA-CAIR-Report-English-FINAL-Web.pdf (accessed on 2 September 2019).

9. Safe Work Australia. Work Health and Safety in the Agricultural Industry-2016. Available online: https:// www.safeworkaustralia.gov.au/system/files/documents/1702/whs-in-the-agricultural-industry.pdf (accessed on 2 September 2019).

10. Chae, H.; Min, K.; Park, J.; Kim, K.; Kim, H.; Lee, K. Estimated rate of agricultural injury: The Korean farmers' occupational disease and injury survey. Ann. Occup. Environ. Med. 2014, 26, 8. [CrossRef]

11. Cividino, S.R.S.; Pergher, G.; Zucchiatti, N.; Gubiani, R. Agricultural Health and Safety Survey in Friuli Venezia Giulia. Agriculture 2018, 8, 9. [CrossRef]

12. Fargnoli, M.; Vita, L.; Gattamelata, D.; Laurendi, V.; Tronci, M. A reverse engineering approach to enhance machinery design for safety. In DS 70, Proceedings of the DESIGN 2012, the 12th International Design Conference, Dubrovnik, Croatia, 21-24 May 2012; Marjanovic, D., Storga, M., Pavkovic, N., Bojcetic, N., Eds.; International Design Conference: Dubrovnik, Croatia, 2012; pp. 627-636, ISBN 978-953-7738-17-4.

13. Yoder, A.M.; Sorensen, J.A.; Foster, F.; Myers, M.; Murphy, D.; Cook, G.; May, J.; Jenkins, P. Selecting Target Populations for ROPS Retrofit Programs in Pennsylvania and Vermont. J. Agric. Saf. Health 2013, 19, 175-190. [CrossRef]

14. Jadhav, R.; Achutan, C.; Haynatzki, G.; Rajaram, S.; Rautiainen, R. Risk factors for agricultural injury: A systematic review and meta-analysis. J. Agromed. 2015, 20, 434-449. [CrossRef]

15. Cavallo, E.; Ferrari, E.; Bollani, L.; Coccia, M. Attitudes and behaviour of adopters of technological innovations in agricultural tractors: A case study in Italian agricultural system. Agric. Syst. 2014, 130, 44-54. [CrossRef]

16. Hallman, E.M. ROPS retrofitting: Measuring effectiveness of incentives and uncovering inherent barriers to success. J. Agric. Saf. Health 2005, 11, 75-84. [CrossRef] [PubMed]

17. Cavallo, E.; Langle, T.; Bueno, D.; Tsukamoto, S.; Görücü, S.; Murphy, D. Rollover protective structure (ROPS) retrofitting on agricultural tractors: Goals and approaches in different countries. J. Agromed. 2014, 19, 208-209. [CrossRef]

18. Schwab, C.V.; Arbuckle, J.G.; Hanna, H.M. Barriers and Motivators for Tractors ROPS Retrofitting in Iowa. J. Agric. Saf. Health 2019, 25, 1-9. [CrossRef]

19. Ayers, P.; Khorsandi, F.; Wang, X.; Araujo, G. ROPS designs to protect operators during agricultural tractor rollovers. J. Terramech. 2018, 75, 49-55. [CrossRef]

20. Myers, M.L.; Cole, H.P.; Westneat, S.C. Injury severity related to overturn characteristics of tractors. J. Saf. Res. 2009, 40, 165-170. [CrossRef]

21. Rondelli, V.; Casazza, C.; Martelli, R. Tractor rollover fatalities, analyzing accident scenario. J. Saf. Res. 2018, 67, 99-106. [CrossRef] 
22. Sun, C.; Nakashima, H.; Shimizu, H.; Miyasaka, J.; Ohdoi, K. Physics engine application to overturning dynamics analysis on banks and uniform slopes for an agricultural tractor with a rollover protective structure. Biosyst. Eng. 2019, 185, 150-160. [CrossRef]

23. Erkol, Z.; Buken, B.; Hekimoglu, Y.; Erkol, H.; Ince, H.; Erzengin, O.U. Analysis of tractor-related deaths. J. Agromed. 2013, 18, 87-97. [CrossRef]

24. Pessina, D.; Facchinetti, D. A survey on fatal accidents for overturning of agricultural tractors in Italy. Chem. Eng. Trans. 2017, 58, 79-84. [CrossRef]

25. Fargnoli, M.; Laurendi, V.; Tronci, M. Design for safety in agricultural machinery. In DS 60, Proceedings of the DESIGN 2010, the 11th International Design Conference, Dubrovnik, Croatia, 17-20 May 2010; Marjanovic, D., Storga, M., Pavkovic, N., Bojcetic, N., Eds.; International Design Conference: Dubrovnik, Croatia, 2010; pp. 701-710, ISBN 978-953-7738-03-7.

26. Cecchini, M.; Colantoni, A.; Monarca, D.; Cossio, F.; Riccioni, S. Survey on the status of enforcement of European directives on health and safety at work in some farms of central Italy. Chem. Eng. Trans. 2017, 58, 103-108. [CrossRef]

27. Kumar, A.; Varghese, M.; Mohan, D. Equipment-related injuries in agriculture: An international perspective. Inj. Control Saf. Promot. 2000, 7, 175-186. [CrossRef]

28. Kogler, R.; Quendler, E.; Boxberger, J. Occupational accidents with agricultural machinery in Austria. J. Agromed. 2016, 21, 61-70. [CrossRef] [PubMed]

29. Irwin, A.; Poots, J. Investigation of UK farmer go/no-go decisions in response to tractor-based risk scenarios. J. Agromed. 2018, 23, 154-165. [CrossRef] [PubMed]

30. Myers, M.L. Folding ROPS or automatically deployable ROPS? J. Agric. Saf. Health 2015, 21, $201-204$. [CrossRef]

31. Vallone, M.; Bono, F.; Quendler, E.; Febo, P.; Catania, P. Risk exposure to vibration and noise in the use of agricultural track-laying tractors. Ann. Agric. Environ. Med. 2016, 23, 591-597. [CrossRef]

32. Jamshidi, N.; Abdollahi, S.M.; Maleki, A. A survey on the actuating force on brake and clutch pedal controls in agricultural tractor in use in Iran. Pol. Ann. Med. 2016, 23, 113-117. [CrossRef]

33. Antunes, S.M.; Cordeiro, C.; Teixeira, H.M. Analysis of fatal accidents with tractors in the Centre of Portugal: Ten years analysis. Forens. Sci. Int. 2018, 287, 74-80. [CrossRef]

34. Jones, C.B.; Day, L.; Staines, C. Trends in tractor related fatalities among adults working on farms in Victoria, Australia, 1985-2010. Accid. Anal. Prev. 2013, 50, 110-114. [CrossRef]

35. Karbeyaz, K.; Şimşek, Ü.; Yilmaz, A. Deaths Related to Tractor Accidents in Eskişehir, Turkey: A 25-Year Analysis. J. Forens. Sci. 2019, 64, 1731-1734. [CrossRef]

36. Tormoehlen, S.A.; Field, W.E. Summary of Indiana Farm Fatalities Involving Individuals 55 Years and Older-1988-2017. Safety 2019, 5, 39. [CrossRef]

37. Houshyar, E.; Houshyar, M. Tractor safety and related injuries in Iranian farms. Saf. Sci. 2018, 103, 88-93. [CrossRef]

38. Caffaro, F.; Lundqvist, P.; Micheletti Cremasco, M.; Nilsson, K.; Pinzke, S.; Cavallo, E. Machinery-Related Perceived Risks and Safety Attitudes in Senior Swedish Farmers. J. Agromed. 2018, 23, 78-91. [CrossRef] [PubMed]

39. Irwin, A.; Caruso, L.; Tone, I. Thinking ahead of the tractor: Driver safety and situation awareness. J. Agromed. 2019, 24, 288-297. [CrossRef] [PubMed]

40. Fargnoli, M.; Lombardi, M.; Puri, D. Applying Hierarchical Task Analysis to Depict Human Safety Errors during Pesticide Use in Vineyard Cultivation. Agriculture 2019, 9, 158. [CrossRef]

41. Colantoni, A.; Monarca, D.; Laurendi, V.; Villarini, M.; Gambella, F.; Cecchini, M. Smart Machines, Remote Sensing, Precision Farming, Processes, Mechatronic, Materials and Policies for Safety and Health Aspects. Agriculture 2018, 8, 47. [CrossRef]

42. Molari, G.; Ayers, P.D.; Meyer, H.G.; Rondelli, V. Special Issue: Engineering advances to improve the safety of agricultural machines. Biosyst. Eng. 2019, 185, 1-3. [CrossRef]

43. Moher, D.; Liberati, A.; Tetzlaff, J.; Altman, D.G. Preferred reporting items for systematic reviews and meta-analyses: The prisma statement. Int. J. Surg. 2010, 8, 336-341. [CrossRef]

44. Thomé, A.M.T.; Scavarda, L.F.; Scavarda, A.J. Conducting systematic literature review in operations management. Prod. Plan. Control 2016, 27, 408-420. [CrossRef] 
45. Enya, A.; Pillay, M.; Dempsey, S. A Systematic Review on High Reliability Organisational Theory as a Safety Management Strategy in Construction. Safety 2018, 4, 6. [CrossRef]

46. Mongeon, P.; Paul-Hus, A. The journal coverage of Web of Science and Scopus: A comparative analysis. Scientometrics 2016, 106, 213-228. [CrossRef]

47. Massaro, M.; Dumay, J.; Guthrie, J. On the shoulders of giants: Undertaking a structured literature review in accounting. Acc. Audit. Acc. J. 2016, 29, 767-801. [CrossRef]

48. Carnevalli, J.A.; Miguel, P.A.C. Review, analysis and classification of the literature on QFD-Types of research, difficulties and benefits. Int. J. Prod. Econ. 2008, 114, 737-754. [CrossRef]

49. Verbano, C.; Venturini, K. Managing risks in SMEs: A literature review and research agenda. J. Technol. Manag. Innov. 2013, 8, 186-197. [CrossRef]

50. Verbano, C.; Venturini, K. Development paths of risk management: Approaches, methods and fields of application. J. Risk Res. 2011, 14, 519-550. [CrossRef]

51. Ho, W.; Zheng, T.; Yildiz, H.; Talluri, S. Supply chain risk management: A literature review. Int. J. Prod. Res. 2015, 53, 5031-5069. [CrossRef]

52. European Union (EU). Directive 2006/42/EC of the European Parliament and of the Council of 17 May 2006 on Machinery, and Amending Directive 95/16/EC. Available online: https://eur-lex.europa.eu/legal-content/ EN/ALL/?uri=celex:32006L0042 (accessed on 2 September 2019).

53. Llory, M. Human-and work-centred safety: Keys to a new conception of management. Ergonomics 1997, 40, 1148-1158. [CrossRef]

54. Karwowski, W. Ergonomics and human factors: The paradigms for science, engineering, design, technology and management of human-compatible systems. Ergonomic 2005, 48, 436-463. [CrossRef]

55. Houssin, R.; Sun, H.; Gardoni, M. A behavioural design approach to improving mechanical system design with integration of use conditions. Int. J. Des. Innov. Res. 2010, 5, 1-24.

56. Sadeghi, L.; Dantan, J.Y.; Mathieu, L.; Siadat, A.; Aghelinejad, M.M. A design approach for safety based on Product-Service Systems and Function-Behavior-Structure. CIRP J. Manuf. Sci. Technol. 2017, 9, 44-56. [CrossRef]

57. European Union (EU). Guide to application of the Machinery Directive 2006/42/EC. Edition 2.2-October 2019. Available online: https:/osha.europa.eu/it/legislation/guidelines/guide-application-machinery-directive200642ec (accessed on 25 November 2019).

58. International Labour Office (ILO). Safety and Health in Agriculture; ILO Code of Practice; International Labour Office: Geneva, Switzerland, 2011. Available online: https://www.ilo.org/global/topics/safety-andhealth-at-work/normative-instruments/code-of-practice/WCMS_161135/lang--en/index.htm (accessed on 2 September 2019).

59. Hagel, L.; King, N.; Dosman, J.A.; Lawson, J.; Trask, C.; Pickett, W.; Saskatchewan Farm Injury Cohort Study Team. Profiling the safety environment on Saskatchewan farms. Saf. Sci. 2016, 82, 103-110. [CrossRef]

60. Pinzke, S.; Svennefelt, C.A.; Lundqvist, P. Occupational injuries in Swedish agriculture-development and Preventive actions. J. Agric. Saf. Health 2018, 24, 193-211. [CrossRef]

61. Vinayak, K.; Kodali, R. Benchmarking the quality function deployment models. Benchmarking Int. J. 2013, 20, 825-854. [CrossRef]

62. Ayers, P.D.; Rondelli, V. Tractor ROPS and stability research: Introduction to this special issue. J. Agric. Saf. Health 2016, 22, 213-214. [CrossRef]

63. Mann, A.; Dee Jepsen, S. Using expert panel data to guide youth agricultural safety and health training resources in the US. Safety 2017, 3, 4. [CrossRef]

64. Franceschetti, B.; Rondelli, V.; Ciuffoli, A. Comparing the influence of roll-over protective structure type on tractor lateral stability. Saf. Sci. 2019, 115, 42-50. [CrossRef]

65. Mazzetto, F.; Bietresato, M.; Gasparetto, A.; Vidoni, R. Simulated stability tests of a small articulated tractor designed for extreme-sloped vineyards. Agric. Eng. 2013, XLIV(s2), 663-668. [CrossRef]

66. Khorsandi, F.; Ayers, P.D.; Freeland, R.S.; Wang, X. Modeling the effect of liquid movement on the center of gravity calculation of agricultural vehicles. J. Terramech. 2018, 75, 37-48. [CrossRef]

67. Franceschetti, B.; Capacci, E.; Rondelli, V. Effects of rubber tracks on narrow-track tractors on the non-continuous rolling prediction model. J. Agric. Saf. Health 2016, 22, 262-273. [CrossRef]

68. Seyedabadi, E. Finite element analysis of lift arm of a MF-285 tractor three-point hitch. J. Failure Anal. Prev. 2015, 15, 737-743. [CrossRef] 
69. Bhondave, B.; Ganesan, T.; Varma, N.; Renu, R.; Sabarinath, N. Design and development of electro hydraulics hitch control for agricultural tractor. SAE Int. J. Commer. Veh. 2017, 10, 405-410. [CrossRef]

70. Alfaro, J.R.; Arana, I.; Arazuri, S.; Jarén, C. Assessing the safety provided by SAE J2194 Standard and Code 4 Standard code for testing ROPS, using finite element analysis. Biosyst. Eng. 2010, 105, 189-197. [CrossRef]

71. Guan, J.; Hsiao, H.; Zwiener, J.V.; Current, R.S.; Lutz, T.J.; Cantis, D.M.; Powers, J.R., Jr.; Newbraugh, B.H.; Spahr, J.S. Evaluating the protective capacity of two-post ROPS for a seat-belted occupant during a farm tractor overturn. J. Agric. Saf. Health 2011, 17, 15-32. [CrossRef] [PubMed]

72. Latorre-Biel, J.I.; Ballesteros, T.; Arana, I.; Alfaro, J.R. Development of an inexpensive rollover energy dissipation device to improve safety provided by ROPS. Biosyst. Eng. 2019, 185, 88-102. [CrossRef]

73. Alkhaledi, K.; Means, K.; McKenzie, E., Jr.; Smith, J. Reducing occupational fatalities by using NIOSH 3rd generation automatically deployable rollover protective structure. Saf. Sci. 2013, 51, 427-431. [CrossRef]

74. Monarca, D.; Cecchini, M.; Colantoni, A.; Di Giacinto, S.; Menghini, G.; Longo, L. Study on the possibility of application of a compact roll over protective structure for agricultural wheeled narrow track tractors. J. Agric. Eng. 2013, XLIV(s2), e136, 681-685. [CrossRef]

75. Monarca, D.; Cecchini, M.; Di Giacinto, S.; Bedini, R.; Ghignoli, A.; Colopardi, F.; Rapiti, R. Comparison between Different Protective Devices for Agricultural Wheeled Narrow Track Tractors and a Risk Index in Orchard Work. Contemporary Eng. Sci. 2015, 8, 1205-1213. [CrossRef]

76. Ayers, P.D.; Khorsandi, F.; John, Y.; Whitaker, G. Development and evaluation of a computer-based ROPS design program. J. Agric. Saf. Health 2016, 22, 247-260. [CrossRef]

77. Franceschetti, B.; Rondelli, V. Models to predict the force to operate front foldable rollover protective structures for narrow-track tractors. Biosyst. Eng. 2019, 185, 126-134. [CrossRef]

78. Al-Bassit, L.; Tricot, N.; Sayegh, S. Falling-object protective structure for tractors in service: Prototype design and validation. Biosyst. Eng. 2019, 185, 76-87. [CrossRef]

79. Bo, H.; Liang, W.; Yuefeng, D.; Zhenghe, S.; Enrong, M.; Zhongxiang, Z. Design and Experiment on Integrated Proportional Control Valve of Automatic Steering System. IFAC-PapersOnLine 2018, 51, 389-396. [CrossRef]

80. Ahamed, T.; Tian, L.; Takigawa, T.; Zhang, Y. Development of auto-hitching navigation system for farm implements using laser range finder. Trans. ASABE 2009, 52, 1793-1803. [CrossRef]

81. Ruggeri, M.; Ferraresi, C.; Dariz, L.; Malaguti, G. A High Functional Safety Performance Level Machine Controller for a Medium Size Agricultural Tractor. SAE Int. J. Commer. Veh. 2014, 7, 613-618. [CrossRef]

82. Castagnetti, D.; Bertacchini, A.; Spaggiari, A.; Lesnjanin, A.; Larcher, L.; Dragoni, E.; Arduini, M. A novel ball joint wear sensor for low-cost structural health monitoring of off-highway vehicles. Mech. Ind. 2015, 16, 507. [CrossRef]

83. Rovira-Más, F. Sensor architecture and task classification for agricultural vehicles and environments. Sensors 2010, 10, 11226-11247. [CrossRef] [PubMed]

84. Kaizu, Y.; Choi, J. Development of a tractor navigation system using augmented reality. Eng. Agric. Environ. Food 2012, 5, 96-101. [CrossRef]

85. Takai, R.; Yang, L.; Noguchi, N. Development of a crawler-type robot tractor using RTK-GPS and IMU. Eng. Agric. Environ. Food 2014, 7, 143-147. [CrossRef]

86. Ehlers, S.G.; Field, W.E.; Ess, D.R. Methods of collecting and analyzing rearward visibility data for agricultural machinery: Hazard and/or object detectability. J. Agric. Saf. Health 2017, 23, 39-53. [CrossRef]

87. Catania, P.; Vallone, M.; Alleri, M.; Morello, G.; Spartà, G.; Febo, P. Whole body vibrations during field operations in the vineyard. J. Agric. Eng. 2013, XLIV(s2), 710-714. [CrossRef]

88. Cutini, M.; Brambilla, M.; Bisaglia, C. Assessment of a ride comfort number for agricultural tractors: A simplified approach. Biosyst. Eng. 2019, 185, 35-44. [CrossRef]

89. Cutini, M.; Romano, E.; Bisaglia, C. Assessment of the influence of the eccentricity of tires on the whole-body vibration of tractor drivers during transport on asphalt roads. J. Terramech. 2012, 49, 197-206. [CrossRef]

90. Cutini, M.; Costa, C.; Bisaglia, C. Development of a simplified method for evaluating agricultural tractor's operator whole body vibration. J. Terramech. 2016, 63, 23-32. [CrossRef]

91. Cutini, M.; Deboli, R.; Calvo, A.; Preti, C.; Brambilla, M.; Bisaglia, C. Ground soil input characteristics determining agricultural tractor dynamics. Appl. Eng. Agric. 2017, 33, 509. [CrossRef]

92. Sviridova, N.; Sakai, K. Application of photoplethysmogram for detecting physiological effects of tractor noise. Eng. Agric. Environ. Food 2015, 8, 313-317. [CrossRef] 
93. Rakhra, A.K.; Mann, D.D. Evaluation of Implement Monitoring Systems. J. Agric. Saf. Health 2013, 19, 51-67. [CrossRef]

94. Ehlers, S.G.; Field, W.E. Determining the effectiveness of mirrors and camera systems in monitoring the rearward visibility of self-propelled agricultural machinery. J. Agric. Saf. Health 2017, 23, 183-201. [CrossRef]

95. Ehlers, S.G.; Field, W.E. Rearward visibility issues related to agricultural tractors and self-propelled machinery: Contributing factors, potential solutions. J. Agric. Saf. Health 2016, 22, 47-59. [CrossRef]

96. Gilad, I.; Byran, E. Quantifying driver's field-of-view in tractors: Methodology and case study. Int. J. Occup. Saf. Ergon. 2015, 21, 20-29. [CrossRef]

97. Khorsandi, F.; Ayers, P.D. The effect of friction on actuation torques of foldable rollover protective structures. J. Agric. Saf. Health 2018, 24, 227-242. [CrossRef]

98. Khorsandi, F.; Ayers, P.D.; Jackson, D.L.; Wilkerson, J. The effect of speed on foldable ROPS actuation forces. J. Agric. Saf. Health 2016, 22, 285-298. [CrossRef]

99. Pessina, D.; Facchinetti, D.; Giordano, D.M. Narrow-track agricultural tractors: A survey on the load of the hand-operated foldable rollbar. J. Agric. Saf. Health 2016, 22, 275-284. [CrossRef] [PubMed]

100. Casazza, C.; Martelli, R.; Rondelli, V. Evaluation of a commercial tractor safety monitoring system using a reverse engineering procedure. J. Agric. Saf. Health 2016, 22, 215-225. [CrossRef] [PubMed]

101. Rondelli, V.; Martelli, R.; Casazza, C.; Guarnieri, A. Methodological approach to assess tractor stability in normal operation in field using a commercial warning device. J. Agric. Eng. 2013, XLIV(s2), e132, 659-662. [CrossRef]

102. Caffaro, F.; Cavallo, E. Comprehension of safety pictograms affixed to agricultural machinery: A survey of users. J. Saf. Res. 2015, 55, 151-158. [CrossRef]

103. Caffaro, F.; Mirisola, A.; Cavallo, E. Safety signs on agricultural machinery: Pictorials do not always successfully convey their messages to target users. Appl. Ergon. 2017, 58, 156-166. [CrossRef]

104. Caffaro, F.; Schmidt, S.; Murphy, D.J.; Cavallo, E. Comprehension rates of safety pictorials affixed to agricultural machinery among Pennsylvania rural population. Saf. Sci. 2018, 103, 162-171. [CrossRef]

105. Tebeaux, E. Improving tractor safety warnings: Readability is missing. J. Agric. Saf. Health 2010, 16, 181-205. [CrossRef]

106. Jepsen, S.D. The US Department of Labor's tractor and machinery certification program: Management styles and perceptions held by community stakeholders and instructors. J. Agric. Saf. Health 2012, 18, 217-232. [CrossRef]

107. Vincent, S.K.; Mazur, J.M.; Summey, T.E.; Namkoong, K.; Byrd, A.P. An Evaluation of Behavioral Intent in Appalachian Youth Participating in the CROPS Curriculum. J. Agric. Saf. Health 2019, 25, 25-36. [CrossRef]

108. Bertacchini, A.; Napoletano, G.; Dondi, D.; Larcher, L.; Pavan, P. Optimized energy-aware wireless system for identification of the relative positioning of articulated systems in the free space. IEEE Sens. J. 2014, 14, 1682-1692. [CrossRef]

109. Liu, B.; Koc, A.B. Field tests of a tractor rollover detection and emergency notification system. J. Agric. Saf. Health 2015, 21, 113-127. [CrossRef] [PubMed]

110. Cole, H.P.; Piercy, L.R.; Heinz, K.L.; Westneat, S.C.; Arrowsmith, H.E.; Raymond, K.M. Safety status of farm tractors that operate on public highways in four rural Kentucky counties. J. Agric. Saf. Health 2009, 15, 207-223. [CrossRef] [PubMed]

111. Hard, D.L.; Myers, J.R. Adoption of rollover protective structures (ROPS) on US farm tractors by state: 1993-1995, 2001, and 2004. J. Agric. Saf. Health 2011, 17, 157-172. [CrossRef] [PubMed]

112. Tonelli, S.M.; Donham, K.J.; Leedom-Larson, K.; Sanderson, W.; Purschwitz, M. Retrofitting tractors with rollover protective structures: Perspective of equipment dealers. J. Agric. Saf. Health 2009, 15, 365-375. [CrossRef]

113. Sorensen, J.A.; Jenkins, P.; Bayes, B.; Clark, S.; May, J.J. Cost-effectiveness of a ROPS social marketing campaign. J. Agric. Saf. Health 2010, 16, 31-40. [CrossRef]

114. Harris, J.R.; McKenzie, E.A.; Etherton, J.R.; Cantis, D.M.; Ronaghi, M. ROPS performance during field upset and static testing. J. Agric. Saf. Health 2010, 16, 5-18. [CrossRef]

115. Harris, J.R.; Winn, G.L.; Ayers, P.D.; McKenzie, E.A., Jr. Predicting the performance of cost-effective rollover protective structure designs. Saf. Sci. 2011, 49, 1252-1261. [CrossRef]

116. Poojary, M.R.; Kalamkar, V.R. Validating the simulation results for testing of tractor roll-over protective structures (ROPS). J. Instit. Eng. (India) 2009, 90, 43-46. 
117. Lindhorst, C.M.; Hoy, R.M.; Pitla, S.K.; Kocher, M.F. Dynamic ROPS Test for Tractors over 6000 Kilograms. Trans. ASABE 2018, 61, 53-62. [CrossRef]

118. Guzzomi, A.; Rondelli, V. Narrow-track wheeled agricultural tractor parameter variation. J. Agric. Saf. Health 2013, 19, 237-260. [CrossRef]

119. Arana, J.I.; Alfaro, J.R.; Arazuri, S.; de León, J.P.; Jarén, C. A proposal to improve the sae standard and OECD code 4 standard code for testing ROPS. Trans. ASABE 2011, 54, 1189-1197. [CrossRef]

120. Jarén, C.; Alfaro, J.R.; Arazuri, S.; de León, J.P.; Arana, J.I. Assessing rollover safety provided by ROPS tests following SAE standard J1194 versus OECD code 4. Trans. ASABE 2009, 52, 1453-1460. [CrossRef]

121. Rondelli, V.; Guzzomi, A.L. Selecting ROPS safety margins for wheeled agricultural tractors based on tractor mass. Biosyst. Eng. 2010, 105, 402-410. [CrossRef]

122. Kabir, M.S.N.; Chung, S.O.; Kim, Y.J.; Sung, N.S.; Hong, S.J. Measurement and evaluation of whole body vibration of agricultural tractor operator. Int. J. Agric. Biol. Eng. 2017, 10, 248-255.

123. Fargnoli, M.; Lombardi, M.; Haber, N. A fuzzy-QFD approach for the enhancement of work equipment safety: A case study in the agriculture sector. Int. J. Reliab. Saf. 2018, 12, 306-326. [CrossRef]

124. Tinc, P.J.; Gadomski, A.; Sorensen, J.A.; Weinehall, L.; Jenkins, P.; Lindvall, K. Applying the Consolidated Framework for implementation research to agricultural safety and health: Barriers, facilitators, and evaluation opportunities. Saf. Sci. 2018, 107, 99-108. [CrossRef]

125. Myers, M.L.; Purschwitz, M.A. ROPS deficiency of gray-market tractors. J. Agric. Saf. Health 2012, 18, 129-140. [CrossRef]

126. Bietresato, M.; Mazzetto, F. Increasing the safety of agricultural machinery operating on sloping grounds by performing static and dynamic tests of stability on a new-concept facility. Int. J. Saf. Secur. Eng. 2018, 8, 77-89. [CrossRef]

127. Keskin, S.G.; Keskin, M.; Soysal, Y. Assessing farm tractor incidents and awareness levels of operators for tractor safety issues in the Hatay province of Turkey. J. Agric. Saf. Health 2012, 18, 113-128. [CrossRef]

128. Tillapaugh, J.A.; Murphy, D.J.; Sommer, H.J., III; Garvey, P.M. Operator assessment of tractor roll angle with and without a tractor stability visual feedback device. J. Agric. Saf. Health 2010, 16, 249-264. [CrossRef]

129. Weil, R.; Mellors, P.; Fiske, T.; Sorensen, J.A. A qualitative analysis of power take-off driveline shields: Barriers and motivators to shield use for New York State farmers. J. Agric. Saf. Health 2014, 20, 51-61. [CrossRef] [PubMed]

130. Jenkins, P.L.; Sorensen, J.A.; Yoder, A.; Myers, M.; Murphy, D.; Cook, G.; Wright, F.; Bayes, B.; May, J.J. Prominent barriers and motivators to installing ROPS: An analysis of survey responses from Pennsylvania and Vermont. J. Agric. Saf. Health 2012, 18, 103-112. [CrossRef] [PubMed]

131. Hard, D.L.; McKenzie, E.A.; Cantis, D.; May, J.; Sorensen, J.; Bayes, B.; Madden, E.; Wyckoff, S.; Stone, B.; Maass, J. A demonstration project in New York and Virginia: Retrofitting cost-effective roll-over protective structures (CROPS) on tractors. J. Agric. Saf. Health 2015, 21, 173-185. [CrossRef] [PubMed]

132. Hard, D.L.; McKenzie, E.A.; Cantis, D.; May, J.; Sorensen, J.; Bayes, B.; Madden, E.; Stone, B.; Maass, J. The NIOSH CROPS Demonstration Project: A study in New York and Virginia with an emphasis on youth. J. Agric. Saf. Health 2016, 22, 173-186. [CrossRef] [PubMed]

133. Di Nocera, F.; Ricciardi, O.; Longo, E.; Mastrangelo, S.; Cutini, M.; Bisaglia, C. Attentional control in accidents involving agricultural tractor operators. Ergon. Des. 2018, 26, 17-23. [CrossRef]

134. Lleras, N.O.; Brennan, S.; Murphy, D.; Klena, M.J.; Garvey, P.M.; Sommer, H.J., III. Development of an open-source tractor driving simulator for tractor stability tests. J. Agric. Saf. Health 2016, 22, 227-246. [CrossRef]

135. Lombardi, M.; Fargnoli, M. Prioritization of hazards by means of a QFD-based procedure. Int. J. Saf. Secur. Eng. 2018, 8, 342-353. [CrossRef]

136. Cole, H.; Myers, M.; Westneat, S. Chores at times of fatal or serious injuries associated with tractor overturns with and without rollover protection. Safety 2016, 2, 18. [CrossRef]

137. European Union (EU). Directive 2009/104/EC of the European Parliament and of the Council of 16 September 2009 Concerning the Minimum Safety and Health Requirements for the Use of Work Equipment by Workers at Work. Available online: https:/eur-lex.europa.eu/legal-content/EN/TXT/?uri=CELEX\%3A32009L0104 (accessed on 25 November 2019). 
138. Zambon, I.; Cecchini, M.; Egidi, G.; Saporito, M.G.; Colantoni, A. Revolution 4.0: Industry vs. Agriculture in a Future Development for SMEs. Processes 2019, 7, 36. [CrossRef]

139. Kitchenham, B.; Brereton, O.P.; Budgen, D.; Turner, M.; Bailey, J.; Linkman, S. Systematic literature reviews in software engineering-A systematic literature review. Inf. Softw. Technol. 2009, 51, 7-15. [CrossRef]

(C) 2019 by the authors. Licensee MDPI, Basel, Switzerland. This article is an open access article distributed under the terms and conditions of the Creative Commons Attribution (CC BY) license (http://creativecommons.org/licenses/by/4.0/). 